Life Sciences, Vo1. 33, Sup. I, 1983, pp. 361-364

Printed in the U.S.A.

\title{
SYSTEMIC AND INTRACEREBROVENTRICULAR EFFECTS OF OPIOID PEPTIDES IN \\ WITHDRAWN MORPHINE-DEPENDENT RHESUS MONKEYS
}

\author{
Debra E. Gmerek, Jonathan L. Katz, Charles P. France \\ and James $\mathrm{H}$. Woods \\ Department of Pharmacology, University of Michigan \\ Ann Arbor, Michigan 48109
}

(Received in final form June 26, 1983)

\section{Summary}

\begin{abstract}
The effects of the degradation-resistant enkephalin analogs FK 33-824 and metkephamid were determined after systemic and intracerebroventricular (i.c.v.) administration in withdrawn morphine-dependent rhesus monkeys. Both peptides suppressed completely signs of 12-hr morphine deprivation, as does the prototype mu-receptor agonist morphine. The peptides were 100 and 2000 times more potent, respectively, after i.c.v. than s.c. injection. Thus, although peptidaseresistant, these compounds have restricted entrance into the central nervous system after systemic administration. The i.c.v. administration of compounds in rhesus monkeys should prove to be a valuable tool in the study of peptide ligands for opiate receptors.
\end{abstract}

Centrally acting compounds which are large molecular weight and poorly soluble in lipids have difficulty penetrating the blood-brain barrier (BBB). Some compounds (e.g., peptides) are in addition rapidly metabolized in peripheral tissues. Thus, these compounds may be more readily and economically studied by injecting them directly into the cerebroventricular system. This technique is particularly useful when investigating activities of endogenous opioid peptides and their analogs.

The single-dose suppression (SDS) test in morphinedependent rhesus monkeys is a well-established method for determining various activities of opioids in non-human primates. In this procedure, dependent monkeys $(3 \mathrm{mg} / \mathrm{kg} / 6 \mathrm{hr})$ are deprived of two consecutive maintenance doses of morphine. Single doses of test agents are then administered to the withdrawn animals and their behavior is monitored. Compounds which act at mureceptors suppress signs of abstinence in morphine-deprived dependent monkeys (1). Very few peptides have been studied, in part, perhaps, due to the presumed rapid systemic degradation and poor central nervous system penetration. We have now established a procedure for intracerebroventricular (i.c.v.) administration of opioids in rhesus monkeys. In preparation for 
studies with rapidly degraded (systemically inactive) compounds, we have characterized the effects of two enzyme-resistant peptides, FK 33-824 and metkephamid, in the SDS test after systemic and i.c.v. administration. The relative systemic and i.c.v. potencies for suppressing morphine-abstinence were compared.

\section{MATERIALS AND METHODS}

Cannulation Mature morphine-dependent rhesus monkeys weighing 4-6 kg were anesthetized with ketamine and pentobarbital. They were implanted with stainless steel cannula (Plastic Products) directed towards the lateral cerebral ventricle according to the atlas of Snider and Lee (2). Standard aseptic and stereotaxic techniques were used. Cannula placements were verified by radiography immediately after surgery and every 6 weeks thereafter. Anesthetized monkeys were $x$-rayed before and after injection of metrizamide (15 $\mathrm{mg}$; Winthrop). Only those animals with evidence of dye in the cerebroventricular space were used.

SDS Procedure Rhesus monkeys maintained on $3 \mathrm{mg} / \mathrm{kg}$ morphine sulfate (s.c.) every $6 \mathrm{hr}$ for at least 90 days were deprived of morphine for $12-16 \mathrm{hr}$. Single doses of test agents were then administered by s.c. or i.c.v. routes. The severity of withdrawal was rated at regular intervals by two experienced observers, according to the procedures outlined by Deneau and Seevers (3) and Villarreal (1).

Three to five animals were observed simultaneously. Monkeys were tested at weekly intervals. Each test agent was given to at least 3 monkeys per dose. The withdrawal severity scores at each time point were averaged.

Compounds and Injections FK 33-824 (Sandoz), metkephamid (IY 127623, Eli Lilly) and morphine sulfate (Malinckrodt) were dissolved in sterile water. Doses refer to the particular salt.

The monkeys are trained to come out of their cages for s.c. injections $(0.1 \mathrm{ml} / \mathrm{kg})$. They are placed in restraining chairs for i.c.v. injections. Sterile or aseptic solutions are injected slowly i.c.v. in volumes of 100-500 ul.

\section{RESULTS and DISCUSSION}

Metkephamid and FK 33-824 suppressed morphine-abstinence in a dose-related manner following both routes of administration (FIG 1 and 2). This is in agreement with previous work indicating that metkephamid and FK 33-824 have morphine-like effects $(4,5,6,7,8,9)$. The monkeys weigh an average of $5 \mathrm{~kg}$. Thus, FK 33-824 is approximately 100 times more potent $[(5 \times 5.6) / 0.3]$ in completely suppressing abstinence when given by central compared to systemic routes. Metkephamid is approximately 2000 times [(5x100)/0.3] more potent after i.c.v. injection lassuming that a systemic dose of $100 \mathrm{mg} / \mathrm{kg}$ would completely suppress abstinence). This is in comparison to morphine, which is only 5 times more potent after i.c.v. administration (unpublished observations). Unlike morphine, the highest i.c.v. doses of FK 33-824 and metkephamid caused severe ataxia and apnea, such that naloxone had to be administered as an antidote. The effect of 

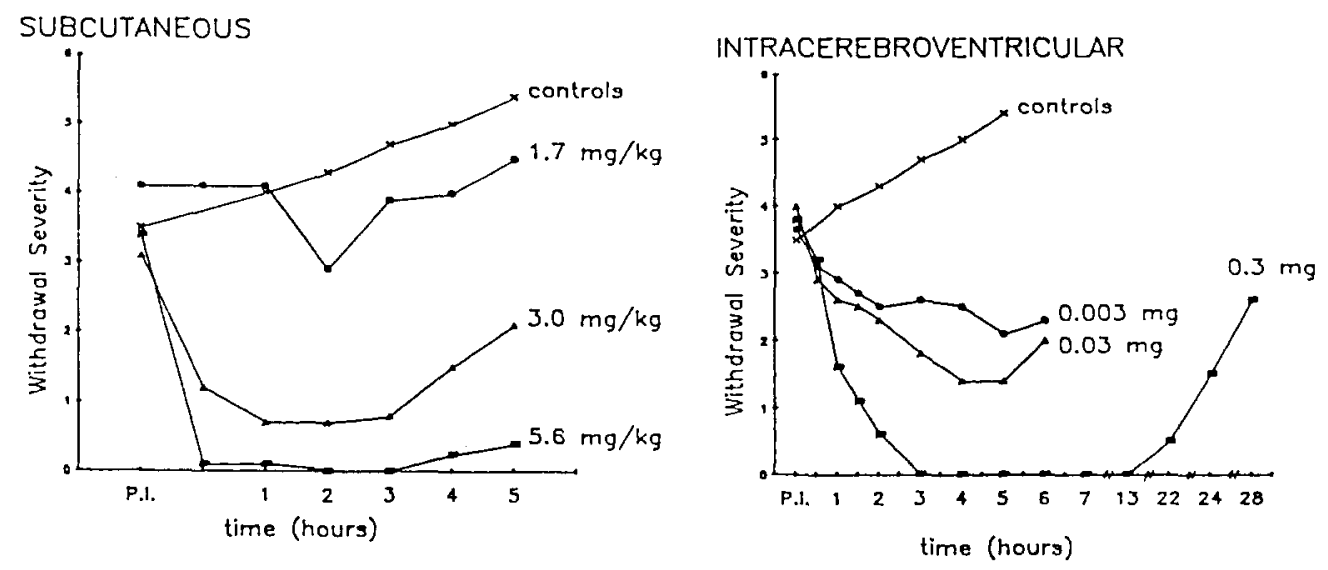

FIG. 1 Effect of FK 33-824 on 12-hr morphine obstinence.
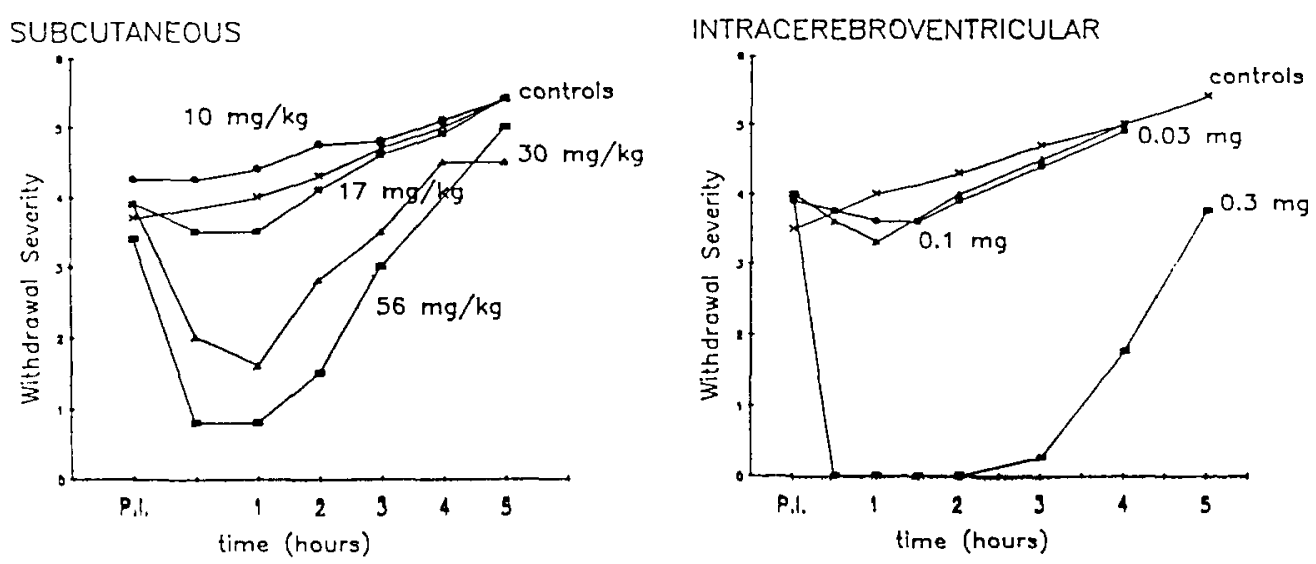

FIG. 2 Effect of metkephamid on 12-hr morphine obstinence. 
the peptides lasted longer than naloxone, however. Whereas an i.c.v. dose of morphine that suppresses abstinence completely lasts for 5 hours (unpublished observations), FK 33-824 completely suppressed withdrawal signs for more than 13 hours after i.c.v. injection.

The dramatic increase in potency and duration of action of FK 33-824 and metkephamid after i.c.v. injection illustrates the effectiveness of the BBB. Therefore, enzymatic stabilization is not always sufficient for accurate assessment of peptide efficacy. We previously found that whereas FK 33-824 and metkephamid share discriminative stimulus properties with morphinelike compounds, they were relatively ineffective as reinforcers after systemic administration in monkeys $(5,7)$. At that time it was suggested that the $B B B$ was responsible for the delayed onset of the discriminative stimulus effect. It is now apparent that the BBB does inhibit entry of FK 33-824 and metkephamid into the central nervous system, which is required for drug discrimination (10). This probably also accounts for the limited reinforcing effects of systemically administered morphine-like peptides. Assessment of opioid peptide efficacy may be best determined by central administration. The i.c.v. administration of compounds in rhesus monkeys should prove to be a valuable tool in the study of peptide ligands for opiate receptors.

\section{ACKNOWLEDGEMENTS}

This study was supported by USPHS grant DA-00254. Metkephamid and FK 33-824 were generously supplied by Drs. R.C.A. Fredrickson and E. Smithwick (Eli Lilly, Co.) and Dr. D. Roemer (Sandoz, I.td.), respectively. We also thank J. Goodrich and F. Adams for their technical assistance.

\section{REFERENCES}

1. J.E. VILLARREAL, Agonist and Antagonist Actions of Narcotic Analgesic Drugs, H.W. Kosterlitz, H.O.J. Collier and J.E. Villarreal, eds. p. 73-93, University Park Press, Baltimore (1973).

2. R.S. SNIDER and J.C. LEE, A Stereotaxic Atlas of the Monkey Brain, University of Chicago Press, Chicago (1961).

3. G.A. DENEAU and M.H. SEEVERS, Proc. 25th Ann Meet, CPDD, NAS (1963) Addendum 25.

4. ROEMER, D., H.H. BUESCHER, R.C. HILI, J. PLESS, W. BAUER, F. CARDINAUX, A. CLOSSE, D. HAUSER and R. HUGUENIN, Nature 268 547-549 (1977).

5. J.H. WOODS, D.W. HEIN, S. HERLING, A.M. YOUNG and R.J. VALENTINO, Endogenous and Exogenous Opiate Agonists and Antagonists, E.L. Way, ed. P. 443-445, Pergamon Press, New York (1979).

6. HERLING, S., E.H. COALE, JR, R.J. VALENTINO, D.W. HEIN and J.H. WOODS, J. Pharmacol. Exp. Ther. 214 139-146 (1980).

7. J.H. WOODS, S. HERLING and A.M. YOUNG, Neuropeptides 1 409-419 (1981).

8. COWAN, A., F.C. TORTELLA and M.W. ADLER, Eur. J. Pharmacol. 71 117-121 (1981).

9. LEANDER, J.D. and C.R. WOOD, Peptides 3 771-773 (1982).

10. R.J. VALENTINO, S. HERLING, J.H. WOODS, F. MEDZIHRADSKY and H. MERZ, J. Pharmacol. Exp. Ther. 217 652-659 (1981). 